\title{
KEWENANGAN BADAN LINGKUNGAN HIDUP DALAM PEMBERIAN SANKSI ADMINISTRATIF TERHADAP PELANGGARAN PENCEMARAN LINGKUNGAN ${ }^{1}$
}

\author{
Oleh : \\ I Made Ari Permadi ${ }^{2}$
}

\begin{abstract}
Abstrack
National economic development as mandated by the Constitution of the Republic of Indonesia Year 1945 organized by the principles of sustainable development and environmentally friendly. Development activities by various human activities have a direct impact on the capacity of the environment, resulting in a shift in the balance of the environment and use of natural resources that is disproportionate and inefficient, lack of awareness of the company as the private sector in environmental management program, causing environmental problems. The environment is a very important part in the human life cycle. Good environment and health is a human right process outlined in the Constitution of the Republic of Indonesia Year 1945 (1945), in Article 28H paragraph (1) of the 1945 Constitution to formulate any person entitled prosperous life physically and mentally, residing, and earn a good living environment and healthy and receive medical care. Spirit of regional autonomy in the governance of the Republic of Indonesia has brought changes and the relationship of authority between the central and local governments, including in the field of environmental protection and management. That environmental quality is declining has threatened the survival of life of humans and other living creatures so that should be the protection and management of the environment seriously and consistently by all stakeholders. Pollution is one of the problems that arose from the development of these technologies. To maintain the preservation of the environment, criminal and administrativesanctions isone deterrenteffectinordertopreservethe environment.
\end{abstract}

\section{Keywords: Environment, Pollution, Authority, Sanctions}

\begin{abstract}
Abstrak
Pembangunan ekonomi nasional sebagaimana diamanatkan oleh Undang-Undang Dasar Negara Republik Indonesia Tahun 1945 diselenggarakan berdasarkan prinsip pembangunan berkelanjutan dan berwawasan lingkungan.Kegiatan pembangunan dengan berbagai aktivitas manusia mempunyai pengaruh langsung terhadap daya dukung lingkungan, sehingga terjadi pergeseran keseimbangan lingkungan dan pemanfaatan sumber daya alam yang tidak proporsional dan tidak efisien, kurangnya kesadaran perusahaan sebagai sektor swasta dalam program pengelolaan lingkungan hidup, menimbulkan permasalahan lingkungan hidup. Lingkungan merupakan bagian yang sangat penting dalam siklus kehidupan manusia. Lingkungan hidup yang baik dan sehat merupakan hak asasi manusia

1 Artikel ini merupakan penelitian/karya ilmiah mahasiswa pada Program Studi Magister (S2) Ilmu Hukum Program Pascasarjana Universitas Udayana.

2 Penulis adalah mahasiswa Magisterlilmu Hukum, Program Pascasarjana Universitas Udayana Denpasar, Bali, email : arixkuman@ymail.com
\end{abstract}


sesuai yang diatur dalam Undang-Undang Dasar Negara Republik Indonesia Tahun 1945(UUD 1945), dalam Pasal 28H ayat(1)UUD 1945 merumuskan setiap orang berhak hidup sejahtera lahir dan batin, bertempat tinggal, dan mendapatkan lingkungan hidup yang baik dan sehat serta berhak memperoleh pelayanan kesehatan.Semangat otonomi daerah dalam penyelenggaraan pemerintahan Negara Kesatuan Republik Indonesia telah membawa perubahan hubungan dan kewenangan antara Pemerintah dan pemerintah daerah, termasuk di bidang perlindungan dan pengelolaan lingkungan hidup.Bahwa kualitas lingkungan hidup yang semakin menurun telah mengancam kelangsungan peri kehidupan manusia dan makhluk hidup lainnya sehingga perlu dilakukan perlindungan dan pengelolaan lingkungan hidup yang sungguh-sungguh dan konsisten oleh semua pemangku kepentingan.Pencemaran merupakan salah satu permasalahan yang timbul akibat perkembangan teknologi tersebut.Untuk menjaga kelestarian fungsi lingkungan hidup, sanksi administrasi dan sanksi pidana merupakan salah satu efek jera guna menjaga kelestarian fungsi lingkungan hidup.

\section{Kata kunci : Lingkungan, Pencemaran, Kewenangan, Sanksi}

\section{PENDAHULUAN}

Hak atas lingkungan hidup yang baik dan sehat merupakan salah satu bentuk hak asasi sebagaimana diatur dalam UUD 1945.Lingkungan merupakan hal yang sangat penting dalam siklus kehidupan manusia serta merupakan aset yang sangat penting untuk dikelola dan dilindungi fungsinya agar dapat dinikmati dari generasi ke generasi. Lingkungan sebagai sumber daya merupakan aset yang dapat menyejahterakan masyarakat. Hal ini sesuai dengan perintah Pasal 33 ayat (3) UUD 1945 yang menyatakan bahwa, bumi, air, dan kekayaan alam yang terkandung di dalamnya dipergunakan untuk sebesar-besarnya kemakmuran rakyat. $^{3}$

Dalam konteks penataan hukum lingkungan, perancangan persyaratan lingkungan menjadi sangat signifikan

3 Supriadi, 2005, Hukum Lingkungan Di Indonesia Sebuah Pengantar, Jakarta, Sinar Grafika, hlm. 4. karena persyaratan lingkungan mempengaruhi keberhasilan program pengelolaan lingkungan. Persyaratan lingkungan yang dirancang dengan baik akan membuat penataan dapat mencapai hasil yang diinginkan. ${ }^{4}$

Perkembangan pembangunan, teknologi, industrialisasi, dan pertumbuhan penduduk yang semakin pesat, semakin memperbesar risiko kerusakan lingkungan hidup. Banyak faktor yang menyebabkan terjadinya pencemarandan perusakan lingkungan, salah satunya adalah yang disebabkan oleh limbah dan sampah. Pencemaran lingkungan memiliki dampak negatif terhadap lingkungan serta kesehatan ekosistem yang terdapat dalam lingkungan tersebut. Banyaknya kasus mengenai tercemarnya sungai-sungai memerlukan perhatian dari semua pihak.

4 Sukanda Husin, 2009, Penegakan hukum Lingkungan Indaonesia, Jakarta, Sinar Grafika, hlm. 139. 
Pencemaran lingkungan adalah berubahnya tatanan lingkungan oleh kegiatan manusia atau proses alami, sehingga mutu kualitas lingkungan turun sampai tingkat tertentu yang menyebabkan lingkungan tidak dapat berfungsi sebagaimana mestinya. ${ }^{5}$

Di Indonesia, perhatian pemerintah terhadap keberadaan perusahaan-perusahaan yang berorientasi pada aspek lingkungan diberikan melalui serangkaian kebijakan dan regulasi tentang lingkungan hidup. Pengaturan mengenai lingkungan diatur dalam Undang-Undang Nomor 32 Tahun2009 tentang Perlindungan dan Pengelolaan Lingkungan Hidup (undang-undang lingkungan hidup). Dalam undangundang lingkungan hidup diatur mengenai dokumen lingkungan yang harus dipenuhi oleh penanggung jawab usaha guna pencegahan pencemaran/ perusakan lingkungan hidup. Usaha pencegahan dalam undang-undang lingkungan hidup dirumuskan dalam Pasal 14 yang merumuskan instrumen pencegahan pencemaran dan/atau kerusakan lingkungan hidup terdiri atas:
a. KLHS
b. Tata ruang
c. Baku mutu lingkungan hidup
d. Kriteria baku kerusakan lingkungan hidup
e. Amdal
f. UKL-UPL
5 Soedjono, 1979, Pengamanan Hukum Terhadap Pencemaran Lingkungan Akibat Industri, Bandung, Alumni,hlm. 19.

g. Perizinan

h. Instrumen ekonomi lingkungan hidup

i. Peraturan perundang-undangan berbasis lingkungan hidup

j. Anggaran berbasis lingkungan hidup

k. Analisis risiko lingkungan hidup

1. Audit lingkungan hidup

m. Instrumen lain sesuai dengan kebutuhan dan/ atau perkembangan ilmu pengetahuan.

Pasal 22 ayat (1) dirumuskan setiap usaha dan/atau kegiatan yang berdampak penting terhadap lingkungan hidup wajib memiliki amdal. Pasal 36 ayat (1) merumuskan setiap usaha dan/atau kegiatan yang wajib memiliki amdal atau UKL-UPL wajib memiliki izin lingkungan.Izin lingkungan merupakan dokumen yang harus dilengkapi oleh penanggung jawab usaha.

Sajipto Rahardjo menyatakan bahwa penegakan hukum pada hakikatnya merupakan usaha untuk mewujudkan ide-ide menjadi kenyataan. $^{6}$ Penegakan hukum merupakan suatu proses yang melibatkan banyak hal. Oleh karena itu, keberhasilan penegakan hukum akan dipengaruhi oleh hal-hal tersebut. Menurut Soerjono Soekanto, ada lima faktor yang mempengaruhi penegakan

6 Satjipto Rahardjo, 2006, Masalah Penegakan Hukum Suatu Tinjauan Sosiologis, Sinar Baru, Bandung, hlm 105. 
hukum. Yaitu faktor hukum itu sendiri, faktor penegak hukum, faktor sarana atau fasilitas, faktor masyarakat dan faktor kebudayaan. ${ }^{7}$

Meski dengan adanya UndangUndang yang mengatur mengenai perlindungan lingkungan hidup, tetap saja terjadi indikasi pencemaran lingkungan. Pelaku-pelaku usaha yang terindikasi melakukan pencemaran lingkungan akan diberikan sanksi sesuai dengan aturan yang berlaku di Indonesia. Saksi yang diatur oleh undang-undang lingkungan hidup adalah mengenai sanksi administrasi dan sanksi pidana.Ketentuan Pasal 76 ayat (1) merumuskan menteri, gubernur, atau bupati/walikota menerapkan sanksi administratif kepada penanggung jawab usaha dan/ atau kegiatan jika dalam pengawasan ditemukan pelanggaran terhadap izin lingkungan. Pelaksanaan pemberian sanksi terhadap pelaku pencemaran lingkungan dilakukan oleh badan lingkungan hidup.

Sanksi adalah salah satu instrumen untuk memaksakan tingkah laku warga agar sesuai dengan hukum. Oleh karena itu, sanksi sering merupakan bagian yang melekat pada norma hukum tertentu. ${ }^{8}$ Sanksi administratif adalah perangkat sarana hukum administratif yang bersifat pembebanan kewajiban/pemerintah dan/atau penarikan kembali keputusan tata usaha negara yang dikenakan

7 Ridwan HR, 2006, Hukum Administrasi Negara, Rajawali Pers, Jakarta, hlm. 313 8 Ibid. kepada penanggung jawab usaha dan/ atau kegiatan atas dasar ketidaktaatan terhadap peraturan perundangundangan di bidang perlindungan dan pengelolaan lingkungan hidup dan/ atau ketentuan dalam izin lingkungan. Pentingnya kewenangan dalam pemberian sanksi administrasi dalam permasalahan pengendalian pencemaran dan perusakan lingkungan hidup,penulistertarikmenjadikan suatu penelitian dengan judul "Kewenangan Badan Lingkungan Hidup Dalam Pemberian Sanksi Pelanggaran Pencemaran Lingkungan”. Adapun permasalahan yang dapat ditarik dari latar belakang diatasa dalah sebagai berikut:BagaimanakewenanganBadan Lingkungan Hidup dalam pemberian sanksi pencemaran lingkungan? Bagaimana ketentuan pemberian sanksi administratif terhadap pelaku pencemaran lingkungan?

Dalam penulisan jurnal ini, peneliti menampilkan orisinalitas penyusunan jurnal yang berbeda dengan penelitian yang lainnya dalam bentuk jurnal maupun tesis yang pembahasannya berkaitan dengan "Kewenangan Badan Lingkungan Hidup Dalam Pemberian Sanksi Pelanggaran Pencemaran Lingkungan", sebagai berikut :Skripsi Ghina Mangala Hadis Putri (Fakultas HukumUniversitas Hasanuddin Bagian Hukum Tata Negara Makassar) yang dilakukan pada Tahun 2013, berjudul "Fungsi Badan Lingkungan Hidup Daerah Terhadap Pemberian Proper 
Dalam Bidang Pertambangan Di Sulawesi Selatan", Jurnal karya Junaidi Satria Labadja (Lex Administratum, Vol.I/No.3/Jul-Sept/2013) yang berjudul "Sanksi Administratif Terhadap Penanggung Jawab Usaha Atas Pelanggaran Izin Lingkungan Hidup", Jurnal karya Amelia M. K. Panambunan (LexAdministratum, Vol. IV/No. 2/Feb/2016) yang berjudul "Penerapan Sanksi Administratif Dalam Penegakan Hukum Lingkungan Di Indonesia”.

Berdasarkan latar belakang serta rumusan permasalahan diatas, tujuan yang ingin dicapai dalam jurnal ini adalah untuk mengetahui kewenangan yang dimiliki oleh badan lingkungan hidup dalam pemberian sanksi serta untuk mengetahui ketentuan dalam pemberian sanksi administratif.

\section{METODE PENELITIAN}

Metode Penelitian yang digunakan dalam penulisan jurnal ini adalah metoda penelitian hukum normatif.Penelitian hukum normatif menguraikan permasalahpermasalahan yang ada, untuk selanjutnya dibahas dengan kajian berdasarkan teori-teori hukum kemudian dikaitkan dengan peraturan perundang-undangan yang berlaku dalam praktek hukum. ${ }^{9}$ Jenis pendekatan yang dipergunakan dalam penelitian ini akan dikaji dengan pendekatan perundang-undangan

9 Soerjono Soekanto,2006, Penelitian Hukum Normatif (Suatu Tinjauan Singkat), PT. Grafindo Persada, Jakarta, hlm.13.
(The Statute Approach) artinya suatu masalah akan dilihat dari aspek hukum dengan mengkaji peraturan perundangundangan.

Bahan hukum yang digunakan dalam penelitian ini adalah bahan hukum primer dan bahan hukum sekunder. Bahan hukum primer merupakan bahan hukum yang mempunyai otoritas.Bahan-bahan hukum primer terdiri dari perundangundangan, catatan-catatan resmi atau risalah dalam pembuatan perundangundangan, dan putusan-putusan hakim. ${ }^{10}$ Bahan hukum primer terdiri dari Undang-Undang Dasar Negara Republik Indonesia Tahun 1945, Undang-Undang Nomor 32 Tahun 2009 Tentang Perlindungan Dan Pengelolaan Lingkungan Hidup, Peraturan Menteri Lingkungan Hidup Republik Indonesia Nomor 02 Tahun 2013 Tentang Pedoman Penerapan Sanksi Administratif Di Bidang Perlindungan Dan Pengelolaan Lingkungan Hidup.

Bahan hukum sekunder merupakan bahan hukum penunjang yang berupa semua publikasi tentang hukum yang bukan merupakan dokumen-dokumen resmi yang meliputi buku-buku, teks yang membicarakan suatu dan/atau beberapa permasalahan hukum, termasuk skripsi, tesis, dan disertasi hukum, jurnal-jurnal hukum.

10 Peter Mahmud Marzuki, 2009, Penelitian Hukum, Kencana Prenada Media Group, Jakarta, hlm.141. 


\section{PEMBAHASAN}

\subsection{Kewenangan}

Badan

Lingkungan Hidup Dalam

Pemberian Sanksi Pencemaran

\section{Lingkungan}

Pemerintah dalam hal penegakan hukum lingkungan telah memiliki pedoman atau dasar yang melandasinya yaitu, UUD 1945, Undang-Undang Nomor 32 Tahun 2009 Tentang Perlindungan Dan Pengelolaan Lingkungan Hidup yang selanjutnya disebut UndangUndang Lingkungan Hidup. Selain pemerintah, penanggung jawab usaha dan masyarakat juga memiliki peran penting dalam pelestarian dan pengelolaan lingkungan.Namun dalam hal pemberian sanksi terhadap pelaku pencemaran lingkungan, kewenangan tersebut dimiliki oleh pemerintah. Dalam Undang-Undang Lingkungan Hidup dimuat mengenai kewenangan pemberian sanksi terkait dengan pelanggaran pencemaran lingkungan. Ketentuan Pasal 76 ayat (1) merumuskan menteri, gubernur, atau bupati/walikota menerapkan sanksi administratif kepada penanggung jawab usaha dan/atau kegiatan jika dalam pengawasan ditemukan pelanggaran terhadap izin lingkungan. Namun pada kenyataan instansi terkait yaitu badan lingkungan hidup yang memberikan sanksi kepada pihak yang melakukan pencemaran lingkungan.

Dalam teori kewenangan, mengenai kewenangan atau wewenang adalah suatu istilah yang digunakan dalam hukum publik, namun terdapat perbedaan diantara keduanya. Kewenangan adalah disebut sebagai "kekuasaan formal", kekuasaan yang berasal dari kekuasaan yang diberikan oleh undang-undang atau legislatif dari kekuasaan eksekutif atau administratif. Sedangkan wewenang hanya mengenai bagian tertentu saja dari kewenangan. Wewenang adalah hak untuk memberi perintah, dan kekuasaan untuk meminta dipatuhi.

Kewenangan yang didapat oleh instansi-instansi pemerintah tersebut diperoleh melalui tiga cara yaitu: secara atribusi, secara delegasi, secara mandat. Berkaitan dengan kewenangan, H.D. Van Willem Konijnenbelt mendefinisikan sebagai berikut :

1. Atribusi adalah pemberian wewenang pemerintahan oleh pembuat undang-undang kepada suatu organ atau badan pemerintahan.

2. Delegasi adalah pelimpahan wewenang pemerintahan dari suatu organ pemerintahan kepada organ pemerintahan lainnya.

3. Mandat terjadi ketika organ pemerintahan mengijinkan kewenangannya dijalankan oleh organ lain atas namanya. ${ }^{11}$

Sedangkan cara memperoleh kewenangan menurut F.A.M. Stroink dan J.G.Steenbeek melalui 2 (dua) cara yaitu dengan atribusi dan delegasi.

11 H.D. Van Willem Konijnenbelt, 1994, Hoofdstukken van Administratief Recht, Utrecht, hlm. 129. 
Atribusi (atributiebevoegdheid) adalah berkenaan dengan penyerahan suatu wewenang baru, sedangkan delegasi (delegatiebevoegdheid) adalah menyangkut pelimpahan wewenang dari wewenang yang telah ada. Untuk wewenang mandat (mandaatbevoegdheid) dikatakan tidak terjadi perubahan wewenang apapun, yang ada hanyalah hubungan internal. $^{12}$

Asas legalitas merupakan salah satu prinsip utama yang dijadikan dasar penyelenggaraan pemerintahan dan negara, khususnya dalam negara hukum.Asas legalitas di dalam hukum administrasi mengandung makna, pemerintah tunduk kepada perundangundangan dan semua ketentuan yang mengikat warga negara harus didasarkan pada undang-undang. Oleh karena itu asas legalitas sebagai landasan kewenangan pemerintah.

Mengenai kewenangan yang dimiliki oleh badan lingkungan hidup dalam pemberian sanksi diperoleh melalui delegasi. Kewenangan tersebut berdasarkan atas UndangUndang Lingkungan Hidup yang dimuat dalam Pasal 71 ayat (2) merumuskan menteri, gubernur, atau bupati/walikota dapat mendelegasikan kewenangannya dalam melakukan pengawasan kepada pejabat/instansi teknis yang bertanggung jawab di bidang perlindungan dan pengelolaan lingkungan hidup.

12 Sadjijono, 2008, Memahami Beberapa Bab Pokok Hukum Adminitrasi, Laksbang Pressindo, Yogyakarta, hlm. 59.
Dalam Peraturan Menteri Lingkungan Hidup Republik Indonesia Nomor 02 Tahun 2013 Tentang Pedoman Penerapan Sanksi Administratif di Bidang Perlindungan Dan Pengelolaan Lingkungan Hidup yang mengatur mengenai pedoman penerapan sanksi administratif yaitupada Pasal 8 ayat (1) menteri, gubernur, atau bupati/walikota sesuai dengan kewenangannya menerapkan sanksi administratif atas pelanggaran yang dilakukan oleh penanggung jawab usaha dan/atau kegiatan terhadap izin lingkungan dan izin perlindungan dan pengelolaan lingkungan hidup. Pasal 8 ayat (2) Dalam melaksanakan kewenangan penerapan sanksi administratif sebagaimana dimaksud pada ayat (1):

a. Menteri dapat menugaskan atau melimpahkan sebagian kewenangannya kepada Pejabat Eselon I yang bertanggungjawab di bidang penataan hukum lingkungan.

b. Gubernur dapat menugaskan atau melimpahkan sebagian kewenangannya kepada Kepala Instansi Lingkungan Hidup Provinsi.

c. Bupati/walikota dapat menugaskan atau melimpahkan sebagian kewenangannya kepada Kepala Instansi Lingkungan Hidup Kabupaten/Kota.

Pasal 8 ayat (3) Penugasan atau pelimpahan sebagian kewenangan sebagaimana dimaksud pada ayat (2) 
ditetapkan dalam keputusan menteri, gubernur, atau bupati/walikota.

\subsection{Ketentuan Pemberian Sanksi AdministratifTerhadapPelaku Pencemaran Lingkungan}

Penegakan hukum administratif dibidang perlindungan dan pengelolaan lingkungan hidup didasarkan atas dua instrument penting, yaitu pengawasan dan penerapan sanksi administratif. Penegakan hukum yang dilakukan oleh birokrasi (pejabat administrasi) berupa penegakan yang bersifat pencegahan, (preventif) yang dilakukan dengan melakukan penyuluhan atau sosialisasi suatu peraturan perundang-undangan, baik peraturan perundang-undangan yang berasal dari pusat maupun peraturan yang dibuat di daerah.

Pengenaan sanksi administratif bertujuanuntukmelindungilingkungan hidup dari pencemaran dan/atau perusakan akibat dari suatu usaha dan/atau kegiatan, menanggulangi pencemaran dan/atau perusakan lingkungan hidup, memulihkan kualitas lingkungan hidup akibat pencemaran dan/atau perusakan lingkungan hidup, dan memberi efek jera bagi penanggung jawab usaha dan/atau kegiatan yang melanggar peraturan perundang-undangan di bidang perlindungan dan pengelolaan lingkungan hidup dan ketentuan dalam izin lingkungan.

Dalam Undang-Undang Lingkungan Hidup mengenai sanksi administratif dimuat dalam :
"Pasal 76 ayat (1) menteri, gubernur, atau bupati/walikota menerapkan sanksi administratif kepada penanggung jawab usaha dan/ atau kegiatan jika dalam pengawasan ditemukan pelanggaran terhadap izin lingkungan."

"Pasal 76 ayat (2) merumuskan sanksi administratif terdiri atas:

a. teguran tertulis

b. paksaan pemerintah

c. pembekuan izin lingkungan

d. pencabutan izin lingkungan."

Dalam Peraturan Menteri

Lingkungan Hidup Republik Indonesia Nomor 02 Tahun 2013 Tentang Pedoman Penerapan Sanksi Administratif Di Bidang Perlindungan Dan Pengelolaan Lingkungan Hidup dijelaskan mengenai sanksi-sanksi administratif yang dapat diberikan kepada pelanggaran lingkungan.

"Pasal 4 ayat (2) merumuskan teguran tertulis sebagaimana dimaksud pada ayat (1) huruf a diterapkan kepada penanggung jawab usaha dan/atau kegiatan yang melakukan pelanggaran terhadap persyaratan dan kewajiban yang tercantum dalam izin lingkungan dan/atau izin perlindungan dan pengelolaan lingkungan hidup, tetapi belum menimbulkan dampak negatif terhadap lingkungan".

"Pasal 4 ayat (3) merumuskan paksaan pemerintah sebagaimana dimaksud pada ayat (1) huruf $b$ diterapkan apabila penanggung jawab usaha dan/atau kegiatan: 
a. Melakukan pelanggaran terhadap persyaratan dan kewajiban yang tercantum dalam izin lingkungan dan/atau izin perlindungan dan pengelolaan lingkungan hidup.

b. Menimbulkan pencemaran dan/atau kerusakan lingkungan hidup".

Pasal 4 ayat (4) merumuskan pembekuan izin lingkungan dan/atau izin perlindungan dan pengelolaan lingkungan hidup sebagaimana dimaksud pada ayat (1) huruf c diterapkan apabila penanggung jawab usaha dan/atau kegiatan:

a. Tidak melaksanakan paksaan pemerintah

b. Melakukan kegiatan selain kegiatan yang tercantum dalam Izin Lingkungan serta Izin Perlindungan dan Pengelolaan Lingkungan

c. Dugaan pemalsuan dokumen persyaratan Izin Lingkungan dan/atau Izin Perlindungan dan Pengelolaan Lingkungan".

Pasal 4 ayat (5) merumuskan pencabutan izin lingkungan dan/atau izin perlindungan dan pengelolaan lingkungan hidup sebagaimana dimaksud pada ayat (1) huruf $d$ diterapkan apabila penanggung jawab usaha dan/atau kegiatan:

a. Memindahtangankan izin usahanya kepada pihak lain tanpa persetujuan tertulis dari pemberi izin usaha.

b. Tidak melaksanakan sebagian besar atau seluruh paksaan pemerintah yang telah diterapkan dalam waktu tertentu.

c. Telah menyebabkan terjadinya pencemaran dan/atau perusakan lingkungan yang membahayakan keselamatan dan kesehatan manusia".

Mekanisme penerapan sanksi administratif dibagi menjadi tiga tahapan. Ketentuan Peraturan Menteri Lingkungan Hidup Republik Indonesia Nomor 02 Tahun 2013 Tentang Pedoman Penerapan Sanksi Administratifyaitu dalam :

"Pasal 5 ayat (2) dirumuskan penerapan sanksi administratif dilakukan melaluimekanisme:

a. Bertahap.

b. Bebas.

c. Kumulatif".

Mekanisme penerapan sanksi tersebut adalah sebagai berikut :

a. Penerapan sanksi bertahap adalah penerapan sanksi administratif secara bertahap yaitu penerapan sanksi yang didahului dengan sanksi administratif yang ringan hingga sanksi yang terberat. Apabila teguran tertulis tidak ditaati maka ditingkatkan penerapan sanksi administratif berikutnya yang lebih berat yaitu paksaan pemerintah atau pembekuan izin, dan sanksisanksi selanjutnya.

b. Penerapan sanksi bebas adalah penerapan sanksi administratif secara bebas yaitu adanya keleluasaan bagi pejabat yang berwenang mengenakan sanksi 
untuk menentukan pilihan jenis sanksi yang didasarkan pada tingkat pelanggaran yang dilakukan oleh penanggung jawab usaha dan/atau kegiatan. Apabila pelanggaran yang dilakukan oleh penanggung jawab usaha dan/atau kegiatan sudah menimbulkan pencemaran dan/atau kerusakan lingkungan hidup, maka dapat langsung dikenakan sanksi paksaan pemerintah

c. Penerapan sanksi kumulatif adalah penerapan sanksi administratif secara kumulatif terdiri atas kumulatif internal dan kumulatif eksternal. Kumulatif internal adalah penerapan sanksi yang dilakukan dengan menggabungkan beberapa jenis sanksi administratif pada satu pelanggaran. Kumulatif ekternal adalah penerapan sanksi yang dilakukan dengan menggabungkan penerapan salah satu jenis sanksi administratif dengan penerapan sanksi lainnya.

Prosedur penerapan sanksi administratif harus memperhatikan beberapa hal yaitu harus dipastikan sesuai dengan peraturan yang menjadi dasar dan Asas-asas Umum Pemerintahan yang Baik, pejabat yang menerapkan sanksi administratif harus dipastikan memiliki kewenangan yang sah berdasarkan peraturan perundang undangan (atribusi, delegasi, atau mandat), ketepatan penerapan sanksi administratif terdiri atas ketepatan bentuk hukum, sanksi administratif ditujukan kepada perbuatan pelanggaran penanggung jawab usaha dan/atau kegiatan. ${ }^{13}$

\section{KESIMPULAN}

Berdasarkan pembahasan diatas dapat disimpulkan sebagai berikut:

1. Kewenangan badan lingkungan hidup dalam penerapan sanksi administrasi terhadap pelaku pelanggaran pencemaran lingkungan dimuat dalam Undang-Undang Nomor 32 Tahun 2009 Tentang Perlindungan Dan Pengelolaan Lingkungan Hidupdan Peraturan Menteri Lingkungan Hidup Republik Indonesia Nomor 02 Tahun 2013 tentang Pedoman Penerapan Sanksi Administratif Di Bidang Perlindungan Dan Pengelolaan Lingkungan Hidup. Badan lingkungan hidup dapat memberikan sanksi terhadap pelanggaran lingkungan sesuai dengan tindakan pelanggaran lingkungan yang dilakukan oleh pelaku.

2. Pada pelanggaran lingkungan hidup diterapkan penegakan hukum administratif yang

13 H. Husni Thamrin, 2013, Penegakan Hukum Administratif Terhadap Pelanggaran Lingkungan Hidup (Jurnal Ilmiah PROGRESSIF), Vol.10 No.30, Desember, hlm. 71 
melalui beberapa tahap yakni teguran, paksaan pemerintah, pembekuan izin lingkungan dan pencabutan izin lingkungan. Sanksi administratif diatur dalam Undang-Undang Nomor 32 Tahun 2009 Tentang Perlindungan Dan Pengelolaan Lingkungan Hidup dan mengenai pelaksanaannya mengacu pada Peraturan Menteri Nomor 2 Tahun 2013 Pedoman Penerapan Sanksi Administratif di Bidang Perlindungan dan Pengelolaan Lingkungan Hidup.

\section{DAFTAR PUSTAKA}

\section{Buku}

H.D. Van Willem Konijnenbelt, 1994, Hoofdstukken van AdministratiefRecht, Utrecht.

Peter Mahmud Marzuki, 2009, Penelitian Hukum, Kencana Prenada Media Group, Jakarta.

Sadjijono, 2008, Memahami Beberapa Bab Pokok Hukum Adminitrasi, Laksbang Yogyakarta.

SatjiptoRahardjo, 2006, Masalah Penegakan Hukum Suatu Tinjauan Sosiologis, Sinar Baru, Bandung.

Soedjono, 1979, Pengamanan Hukum Terhadap Pencemaran Lingkungan Akibat Industri, Bandung, Alumni.

Soerjono Soekanto,2006, Penelitian Hukum Normatif(Suatu Tinjauan Singkat), PT. Grafindo Persada, Jakarta .
Sukanda Husin, 2009, Penegakan hukum Lingkungan Indonesia, Jakarta, Sinar Grafika.

Supriadi, 2005, Hukum Lingkungan Di Indonesia Sebuah Pengantar, Jakarta, Sinar Grafika.

Ridwan HR, 2006, Hukum Administrasi Negara, Rajawali Pers, Jakarta.

\section{Jurnal}

H. HusniThamrin, Penegakan Hukum Administratif Terhadap Pelanggaran Lingkungan Hidup (Jurnal Ilmiah PROGRESSIF), Vol.10 No.30, Desember 2013,

\section{Peraturan}

\section{Perundang-Undangan}

Undang-Undang Dasar Negara Republik Indonesia Tahun 1945.

Undang-Undang Nomor 32 Tahun 2009 Tentang Perlindungan dan Pengelolaan Lingkungan Hidup, Lembaran Negara Republik Indonesia Tahun 2009 Nomor 140.

Peraturan Menteri Nomor 2 Tahun2013PedomanPenerapanSanksi Administratif di Bidang Perlindungan dan Pengelolaan Lingkungan Hidup, Berita Negara Republik Indonesia Tahun 2013 Nomor 314. 